\title{
METHOD FOR CALCULATING THE COMPOSITION OF CELLULAR CONCRETE
}

\author{
${ }^{1}$ Martynov V., Doctor of Technical Sciences, Associate Professor, \\ ogasa_psk@ukr.net, ORCID: 0000-0002-9674-7920 \\ ${ }^{2}$ Martynova O., $\mathrm{PhD}$, Associate Professor, \\ pingu_@ukr.net, ORCID: 0000-0001-7324-2543 \\ ${ }^{2}$ Odessa State Agrarian University \\ 13, st. Panteleimonovskaya, Odessa, 65074, Ukraine \\ ${ }^{1}$ Makarova S., PhD, Associate Professor, \\ svetlana.makarova@ukr.net, ORCID: 0000-0003-3237-1431 \\ ${ }^{1}$ Vietokh O., PhD, Associate Professor, \\ vetoh.ogasa@gmail.com, ORCID: 0000-0003-0672-4387 \\ ${ }^{1}$ Odessa State Academy of Civil Engineering and Architecture \\ 4, Didrikhson st., Odessa, 65029, Ukraine
}

\begin{abstract}
The analysis of existing methods for calculating concrete compositions was carried out. The characteristics and sequence of the calculation-experimental and experimental-calculation methods for the selection of concrete compositions are provided. The advantages and disadvantages of each of the methods are described. These methods are generalized by the general systemic cycle PDCA (Deming cycle), which is determined by the sequence of actions: P (plan) - D (do) - C (check) - A (Action). It was established that for calculating the compositions of the cellular method there is no universal method, which would ensure the achievement of the required strength and average density at the same time. Based on the above, the aim of the thesis was formulated. The aim of the thesis is to develop a method for calculating the composition of cellular concrete, based on experimental-statistical models, which would ensure the production of concrete with the required properties while minimizing the cost of raw materials. A calculation algorithm, a block diagram and a computer program for designing cellular concrete compositions based on experimental-statistical modeling were developed. Using the example of the specified block diagram for calculating concrete compositions, the sequence of calculations is described in detail. The essence of the calculations is that the three-factor mathematical model of the property parameter of cellular concrete, which is supposed to be guaranteed, leads to a second order equation. After that, the roots of the equation are determined. They are substituted into a mathematical model and the composition of concrete is determined in natural values of variable factors. After that, the cost of the composition is determined, which is entered into the data array. Then one of the factors changes, according to the set step and the cycle repeats. At the last stage, the formed data array is processed and the composition with the minimum cost of materials is determined. Testing of the developed software was carried out by processing and calculating a three factor experiment. As a result, the composition of cellular concrete which provides the required strength of foam concrete with a minimum cost of materials, was determined.
\end{abstract}

Keywords: aerated concrete, algorithm, flowchart, computer program, concrete mix calculation, cost.

Introduction. Conservation of natural and energy resources is a priority for the construction industry. This can be achieved by using effective wall and thermal insulation materials, including cellular concrete products. The effectiveness of these materials is ensured by their quality. In turn, the quality of cellular concrete depends to a large extent on the sound design of the composition of the original components.

Analysis of recent research and publications. For more than a century of concrete history, many different methods and methods of designing compositions have been developed. All these methods are of a computational-experimental, or experimental-computational nature $[1,2]$. 
In the first case, the composition is calculated according to the scheme:

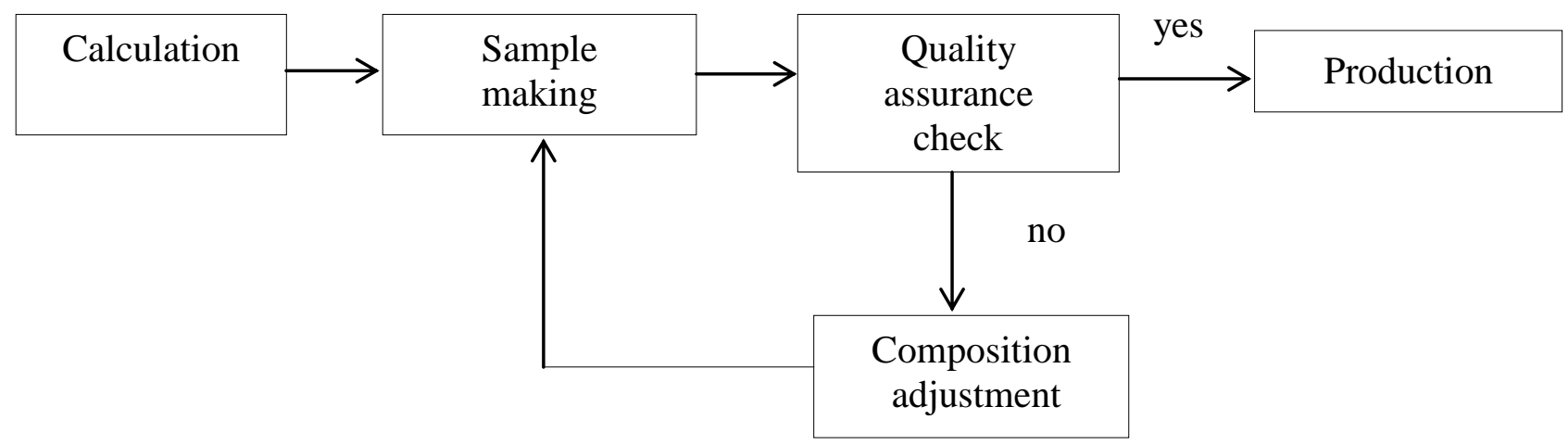

So, for example, the main method of designing heavy concrete compositions - the method of absolute volumes - is of a computational and experimental nature [1]. According to this method, first using the initial assumptions expressed in mathematical form, as well as various empirical information, summarized in the form of tables, graphs and nomograms, a preliminary composition of the components is calculated. Then, on the basis of this composition, laboratory samples are prepared according to the appropriate technology, which are tested at the appropriate age and the necessary characteristics are determined. After that, the obtained indicators are compared with those required for the project. If these indicators coincide, the composition is recommended for use in production. If the indicators do not match, the cycle is repeated. Again, the preliminary composition is calculated or adjusted, samples are made and tested until the required result is achieved. This method is quite lengthy and laborious. In addition, the technique does not take into account the peculiarities of the structure formation of the material.

When applying experimental calculation methods for designing compositions, the calculation is done according to the scheme:

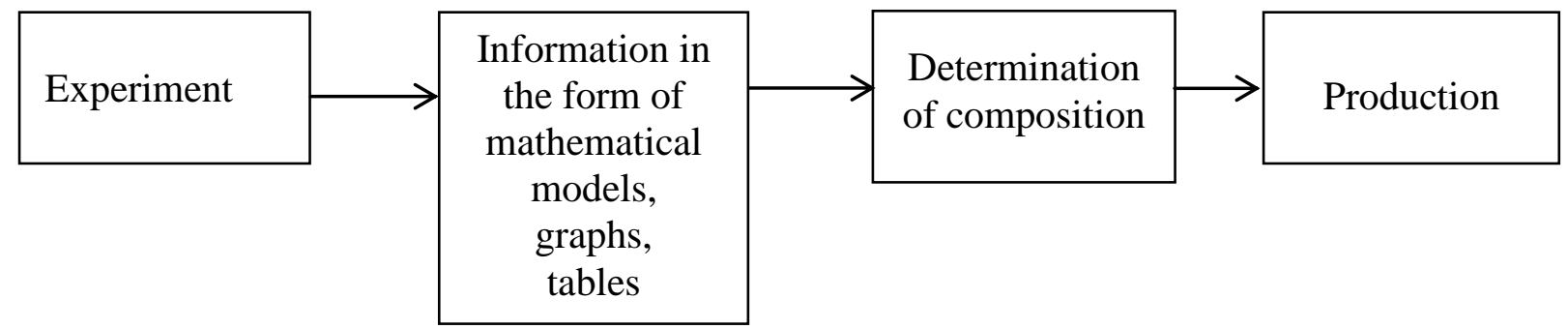

In addition, the results are applied only for concretes obtained with materials with the same characteristics as in the experiment. There is unknown the influence of the so-called uncontrollable factors and the material`s structure.

In both cases, checking the correctness of the appointment of the composition by a set of properties that characterize the quality of the material is carried out according to the so-called Deming cycle (proposed by Dr. Deming, USA) [3].

Another name for the Deming cycle is the PDCA cycle - an abbreviation from the first letters of words in the English alphabet: P (Plan) - drawing up a work plan; D (Do) - action, performance of work in accordance with the plan; $\mathrm{C}$ (Chek) - checking the compliance of the result that was obtained with the planned; A (Action) - taking the necessary measures if the execution result deviates from the planned result.

In the design of concrete formulations by calculation and experimental methods, the Deming cycle is used both in laboratory tests and in testing in production conditions.

Methods for calculating the composition of heavy concrete are aimed at ensuring the required strength of concrete. The task becomes more complicated when designing compositions of lightweight and cellular concrete, where it is necessary to ensure not only strength indicators, but also to obtain a material of the required density.

Bulletin of Odessa State Academy of Civil Engineering and Architecture, 2021, no. 83, page 77-85 
The method for calculating the composition of cellular concrete given in the literature provides for the calculation of the composition to ensure the required density and does not take into account the strength of the material $[4,5]$. The strength is then determined by the manufacture and testing of samples. If the composition does not provide the necessary strength indicators, it is necessary to correct the composition and check it again. Since the branded strength of materials based on Portland cement is determined at the 28th day of age, the process of selecting compositions that provide the required strength can be quite lengthy and laborious. In addition, in the given methodology, a large number of different empirical coefficients are used, depending on the characteristics, materials used and the method of concrete hardening.

In recent years, experimental and computational methods for the selection of compositions of artificial building materials are becoming more and more widespread; mathematical methods of experiment planning are used with the subsequent construction of mathematical models that optimize parameters and making the necessary technological decisions based on them [6, 7]. The increased costs of materials and time at the stage of experimental work are subsequently compensated by a large amount of information.

The aim of this study is to increase the efficiency of the process of choosing the composition of cellular concrete.

Materials and research methods. To do this, it is necessary to develop a flowchart (Fig. 1) and, on its basis, create a program for calculating the composition of cellular concrete, which provides its necessary physical and mechanical parameters at a minimum cost of the product. The experiment is conducting with using mathematical and statistical research methods and calculate mathematical models of cellular concrete properties. There is testing of the software product on a computer.

Calculation algorithm. There is a flowchart in Fig.1 for calculating the composition of cellular concrete with a minimum consumption of raw materials, which ensures the receipt of the material with the required property parameter.

At first, there are introduced the coefficients of the mathematical model, the natural values of the variable factors, the average density in a dry state, to obtain which it is necessary to calculate cellular concrete, the value of the water-solid ratio, and the value of the property parameter to be provided. The costs of raw materials are also entered.

Then the computer starts calculating. The initial values of the coded factors have already been entered into the program $\left(\mathrm{X}_{1} \mathrm{X}_{2} \mathrm{X}_{3}\right.$, which range from -1 to +1$)$. The general view of the mathematical model of a three-factor experiment is as follows:

$$
\mathrm{Y}=\mathrm{B}_{0}+\mathrm{B}_{1} \mathrm{X}_{1}+\mathrm{B}_{2} \mathrm{X}_{2}+\mathrm{B}_{3} \mathrm{X}_{3}+\mathrm{B}_{12} \mathrm{X}_{1} \mathrm{X}_{2}+\mathrm{B}_{13} \mathrm{X}_{1} \mathrm{X}_{3}+\mathrm{B}_{23} \mathrm{X}_{2} \mathrm{X}_{3}+\mathrm{B}_{11} \mathrm{X}_{1}^{2}+\mathrm{B}_{22} \mathrm{X}_{2}^{2}+\mathrm{B}_{33} \mathrm{X}_{3}^{2} \text {, }
$$

where $\mathrm{Y}$ - property parameter that is calculated;

$\mathrm{B}$ - corresponding coefficients of the mathematical model;

$\mathrm{X}$ - corresponding coded values of variable factors.

The two values of the variable factors are first fixed in the program. These are $X_{1}$ and $X_{3}$ in the above flowchart. The calculated values are summed up with the entered property parameter after the initial coded values of these variables are set in the model taking into account the corresponding coefficients. Thus, the model is reduced to a quadratic equation with one unknown. Next, the discriminant of the equation is calculated and compared to zero. If the discriminant is less than 0 , the value of the factor $\mathrm{X}_{2}$ changes according to the step with which this factor changes. For example, if the step is 0.2 , then the next factor value is 0.8 . When the discriminant is greater than 0 , the roots of the equation are calculated - the first and the second. Next the comparison of the obtained values comes, are they within the factor space, that is, from -1 to +1 . If this condition is met, then for a certain solution, the coded values of the factors are converted into natural values. Next, the composition of concrete is calculated using both solutions of the equation. After that, the cost of the composition is calculated, taking into account the cost of materials. The smallest composition in terms of cost is stored in the array that has been formed. 
Program flowchart

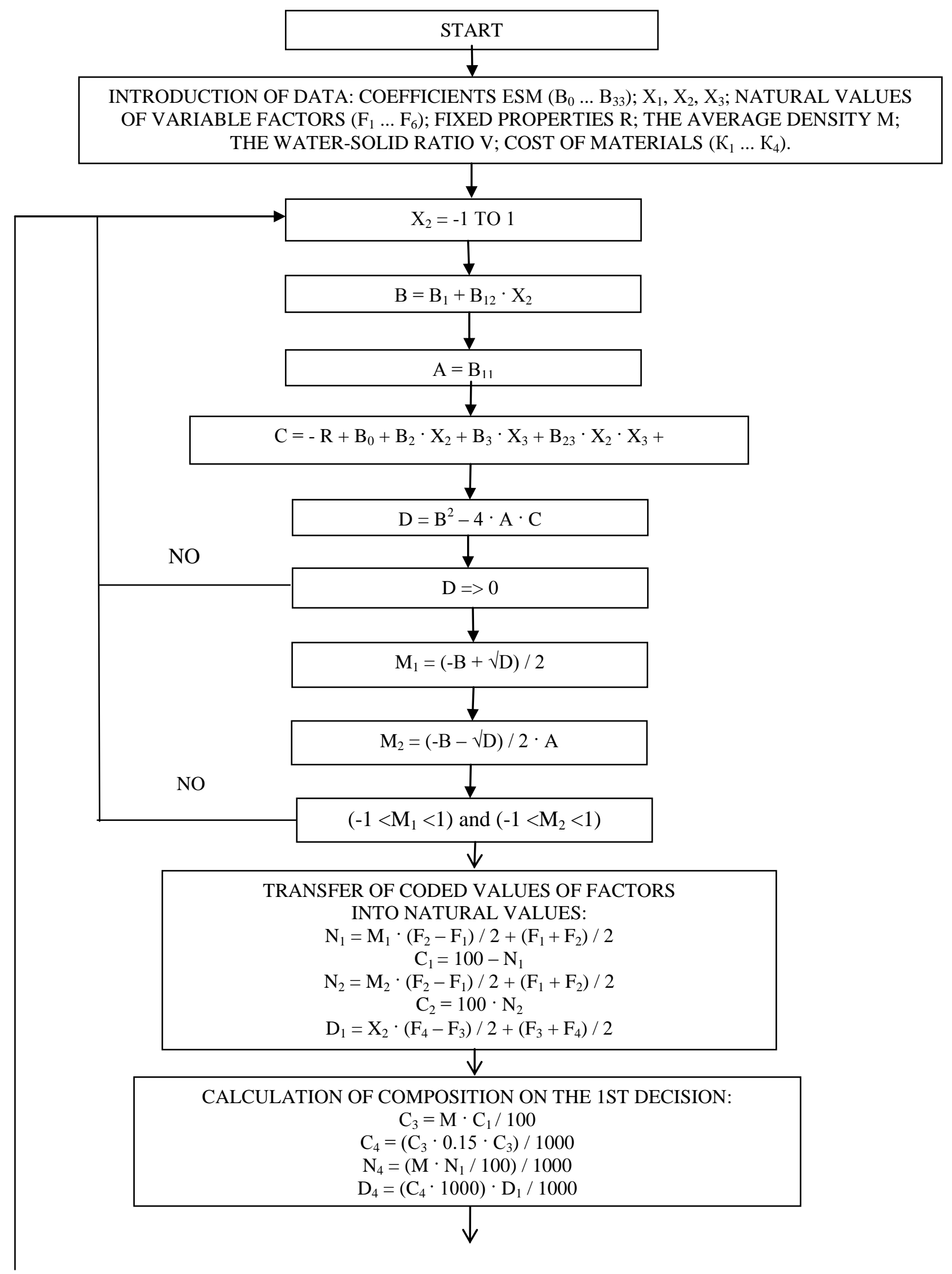


Continuation of the flowchart

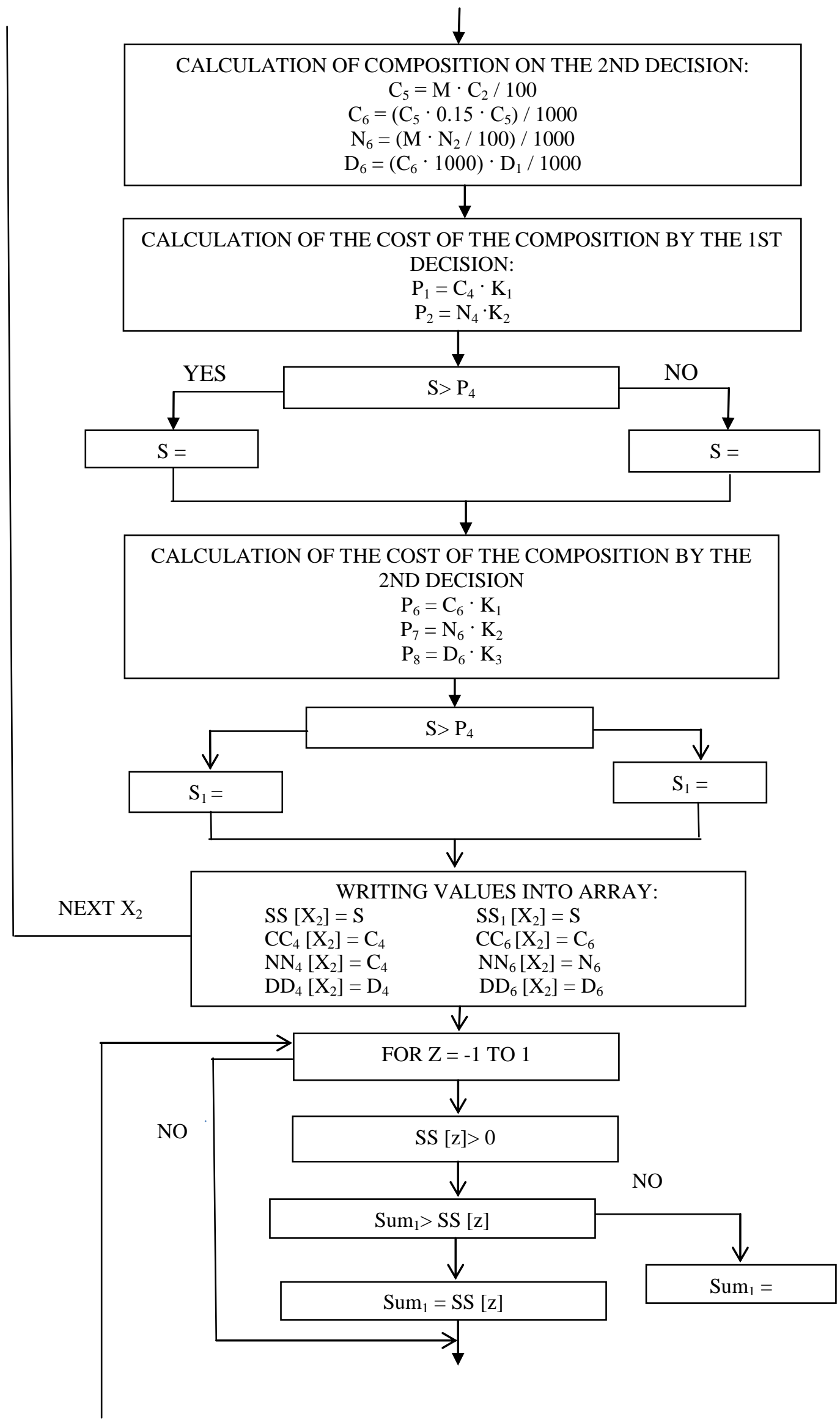




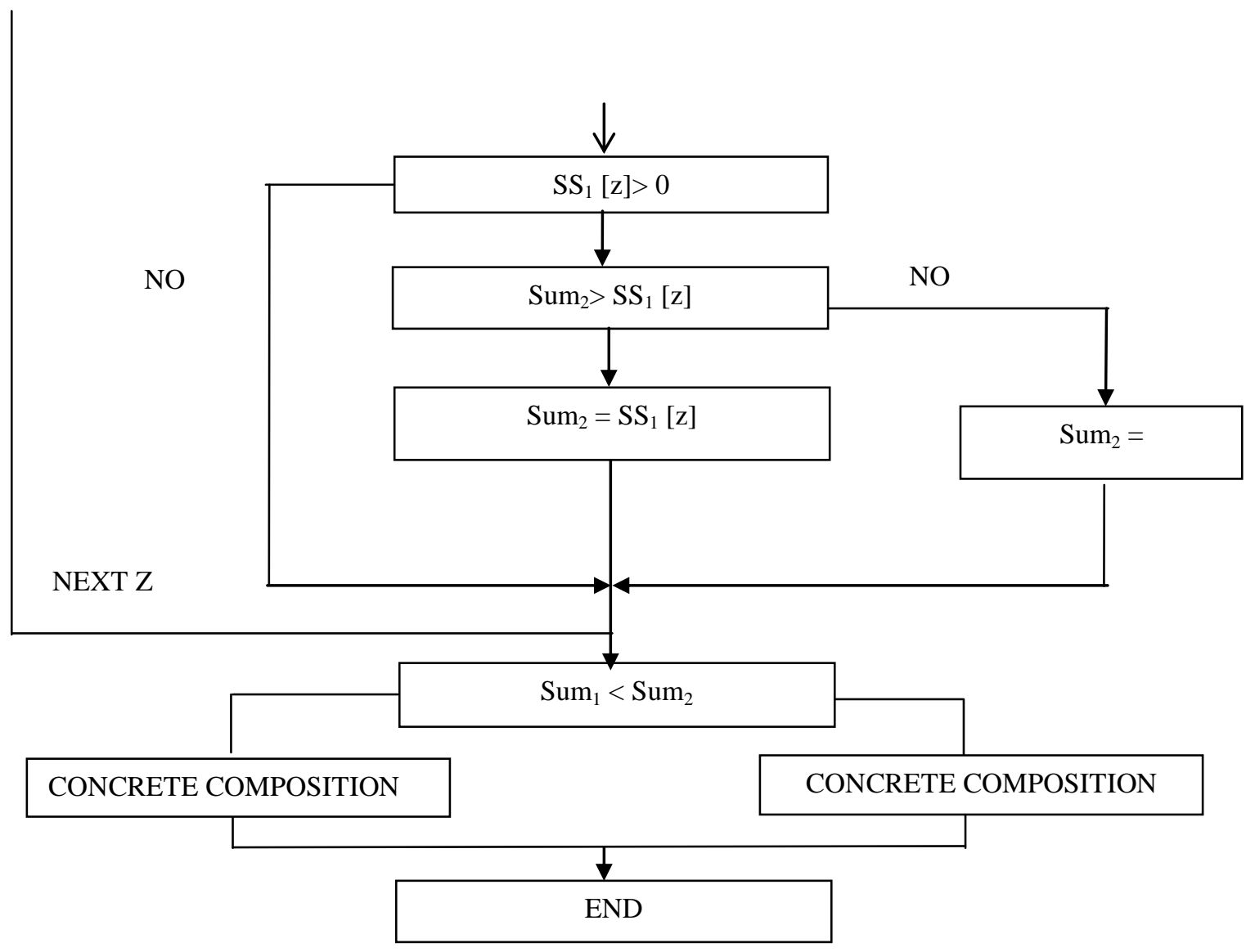

Fig. 1. Flowchart of calculation

The calculation is carried out in the cycle of changing the factor $\mathrm{X}_{2}$ in accordance with the established step of changing this factor. The array of aerated concrete compositions is finally formed taking into account the cost of materials, when all cycle options are enumerated. At the final stage, the cost of the materials of the formed array is calculated. The calculation is also performed in a cycle, as a result of which the composition with the lowest cost price is calculated.

Research results. A three-factor experiment using mathematical methods of experiment planning was carried out for the practical implementation of the software product. The experiment was carried out according to the standard Box-Benkin plan of type B-3. The influence of variable formulation and technological factors on the properties of non-autoclaved foam concrete with an average density of $600 \mathrm{~kg} / \mathrm{m}^{3}$ was studied.

These factors were chosen: $\mathrm{X}_{1}-$ the content of the filler in the mixture with cement. This factor varied from 0 to $30 \%$ of the total mass of the mixture. $\mathrm{X}_{2}-$ is the content of the cement hardening accelerator additive, 0-3 percent of the cement mass in dry matter. $X_{3}-$ is the duration of the activation of the solution mixture in the reactor of the high-speed mixer, varied from 0 to 40 seconds. The water demand of the mixture according to the water-solid ratio was constant and amounted to 0.41 .

A mathematical model was built as a result of the implementation of the experiment and processing of its results, which is adequately described by the logarithm of foam concrete strength (2).

$$
\begin{aligned}
& \ln (R)=1,011-0,157 b_{1}+0,245 b_{2}+0,271 b_{3}-0,118 b_{12}+0,118 b_{13}-0,16 b_{23}+ \\
& +0,148 b_{11}^{2}-0,181 b_{22}^{2}-0,181 b_{33}^{2}
\end{aligned}
$$

A screen copies of the final working panel of the program for calculating the composition of cellular concrete is shown in Fig. 2. 


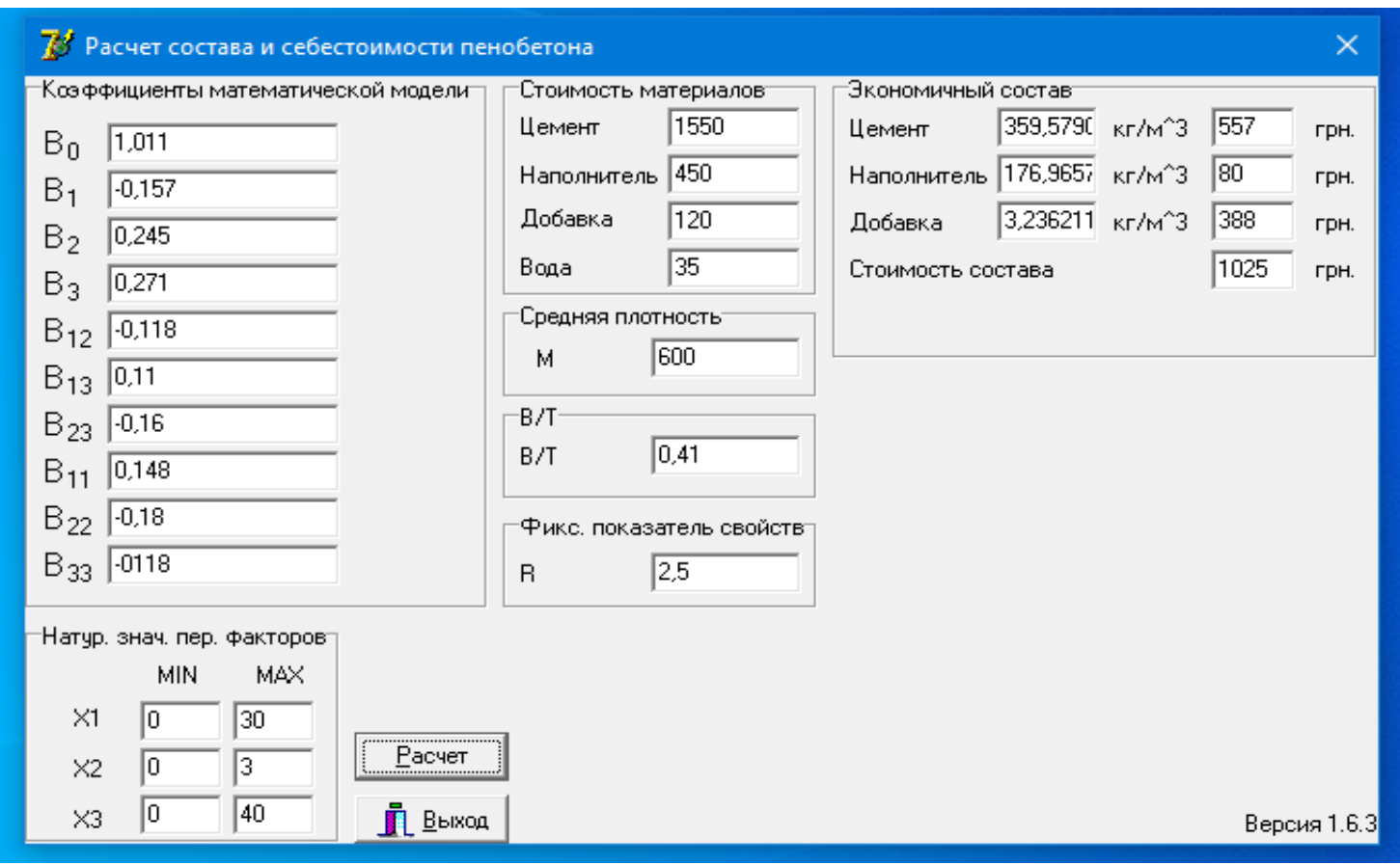

Fig. 2. View of the working panel of the program for calculating the composition of cellular concrete

Conclusions and prospects for further research. The given experimental and computational method of designing cellular concrete compositions based on experimental and statistical modeling makes it possible to design compositions not only with a given average density, but also with the necessary physical and mechanical indicators: strength, water absorption, water resistance, etc., which have a minimum cost.

The effectiveness of the developed product can be increased by improving it. First of all, due to the development of a program for calculating the composition of concrete, which took into account two or more mathematical models of properties, the so-called multi-parameter optimization.

\section{References}

[1] L.Y. Dvorkin, O.L. Dvorkin, YU.V. Hornits'kiy, Proektuvannya skladiv betonu Iz zadanymy vlastivostyami. Rivne: RDTU, 2000.

[2] V.S. Ramachandran, R.F. Feldman, J.J. Beaudoin, Concrete Science: A Treatise on Current Research. 1st Edition. Chichester, West Sussex: Wiley Heyden, 1982.

[3] Deming, W. Edwards, Out of the crisis. Cambridge, Mass.: Massachusetts Institute of Technology, Center for Advanced Engineering Study, 1986.

[4] E.K.K. Nambiar, K. Ramamurthy, "Models relating mixture composition to the density and strength of foam concrete using response surface methodology", Cement and Concrete Composites, no. 28, pp. 752-760, 2006.

[5] S. Solodkyy, V. Kahanov, I. Hornikovska, Y. Turba, "A study of fracture touchness of heavyweight concrete and foam concrete reinforced by polypropylene fiber for road construction", Eastern-European Journal of Enterprise Technologies, no. 4/5 (76), pp. 40-46, 2015.

[6] T. Lyashenko, S. Kryukovskaya, "Modelling the influence of composition on rheological parameters and mechanical properties of fibre reinforced polymer-cement mortars", Brittle Matrix Composites 10. Cambridge: Woodhead Publ. Ltd., Warsaw: IFTR, pp. 169178, 2012.

[7] T.V. Lyashenko, "Composition-process fields methodology for design of composites structure and properties", Brittle Matrix Composites 11, Insitute of Fundamental Technological Research PAS, pp. 289-298, 2015. 


\title{
МЕТОДИКА РОЗРАХУНКУ СКЛАДУ НІЗДРЮВАТОГО БЕТОНУ
}

\author{
${ }^{1}$ Мартинов В.I., д.т.н., доцент, \\ ogasa_psk@ukr.net, ORCID: 0000-0002-9674-7920 \\ ${ }^{2}$ Мартинова О.Б., к.т.н., доцент, \\ pingu_@ukr.net, ORCID: 0000-0001-7324-2543 \\ ${ }^{2}$ Одеський державний аграрний університет \\ ул. Пантелеймонівська 13, м. Одеса, 65074, Україна \\ ${ }^{1}$ Макарова С.С., к.т.н., доцент, \\ svetlana.makarova@ukr.net, ORCID: 0000-0003-3237-1431 \\ ${ }^{1}$ Ветох О.М., к.Т.н., доцент, \\ vetoh.ogasa@gmail.com, ORCID: 0000-0003-0672-4387 \\ ${ }^{1}$ Одеська державна академія будівництва та архітектури \\ вул. Дідріхсона, 4, м. Одеса, 65029, Україна
}

\begin{abstract}
Анотація. Проведено аналіз існуючих методів розрахунку складів бетону. Наведено характеристики i послідовність розрахунково-експериментального i експериментальнорозрахункового методів підбору складів бетону. Описано переваги і недоліки кожного 3 методів. Узагальнено ці методи загальним системним циклом PDCA (цикл Демінга), що визначає послідовність дій: P (plan) - D (do) - C (chek) - A (Action). Встановлено, що для розрахунку складів ніздрюватого методу не існує універсального методу, який забезпечував би одночасно досягнення необхідної міцності і середньої густини. На підставі цього сформульовано мету роботи. Метою роботи є підвищення ефективності процесу вибору складу ніздрюватого бетону, на основі експериментально-статистичних моделей, який би забезпечував отримання бетону 3 необхідними властивостями при мінімізації вартості вихідних сировинних матеріалів Розроблено алгоритм розрахунку, блок-схему і комп'ютерну програму проектування складів ніздрюватого бетону на основі експериментальностатистичного моделювання. На прикладі, наведеної блок-схеми розрахунку складів бетону, докладно описана послідовність розрахунків. Суть розрахунків полягає в тому, що трьохфакторна математична модель параметра властивості ніздрюватого бетону, який необхідно гарантувати, зводиться до рівняння другого порядку. Після цього визначаються коріння рівняння. Їх підставляють в математичну модель і визначають склад бетону в натуральних значеннях змінних факторів. Після цього визначається вартість складу, яка заноситься в масив. Далі змінюється один з факторів, відповідно, встановленого кроку, і цикл повторюється. На останній стадії обробляється сформований масив і визначається склад з мінімальною вартістю матеріалів. Апробація розробленого програмного забезпечення здійснена обробкою і обчисленнями трьох факторного експерименту. В результаті визначено склад пористого бетону, який забезпечує потрібну міцність пінобетону 3 мінімальною вартістю матеріалів.
\end{abstract}

Ключові слова: пінобетон, алгоритм, блок-схема, комп'ютерна програма, розрахунок складу бетону, собівартість. 


\title{
МЕТОДИКА РАСЧЕТА СОСТАВА ЯЧЕИСТОГО БЕТОНА
}

\author{
${ }^{1}$ Мартынов В.І., д.т.н., доцент, \\ ogasa_psk@ukr.net, ORCID: 0000-0002-9674-7920 \\ ${ }^{2}$ Мартынова О.Б., к.т.н., доцент, \\ pingu_@ukr.net, ORCID:0000-0001-7324-2543 \\ ${ }^{2}$ Одесский государственный аграрный университет \\ ул. Пантелеймоновская, 13, г. Одесса, 65074, Украина \\ ${ }^{1}$ Макарова С.С., к.т.н., доцент, \\ svetlana.makarova@ukr.net, ORCID: 0000-0003-3237-1431 \\ ${ }^{1}$ Ветох А.М., к.т.н., доцент, \\ vetoh.ogasa@gmail.com, ORCID: 0000-0003-0672-4387 \\ ${ }^{1}$ Одесская государственная академия строительства и архитектуры \\ ул. Дидрихсона, 4, г. Одесса, 65029, Украина
}

\begin{abstract}
Аннотация. Проведен анализ существующих методов расчета составов бетона. Приведены характеристики и последовательность расчетно-экспериментального и экспериментально-расчетного методов подбора составов бетона. Описаны достоинства и недостатки каждого из методов. Обобщены эти методы общим системным циклом PDCA (цикл Деминга), что определяет последовательность действий: P (plan) - D (do) - C(chek) - A (Action). Установлено, что для расчета составов ячеистого метода не существует универсального метода, который обеспечивал бы одновременно достижения требуемой прочности и средней плотности. На основании этого сформулирована цель работы. Целью работы есть повышение эффективности процесса подбора состава ячеистого бетона, на основе экспериментально-статистических моделей, который бы обеспечивал получение бетона с требуемыми свойствами при минимизации стоимости исходных сырьевых материалов. Разработано алгоритм расчета, блок-схему и компьютерную программу проектирования составов ячеистого бетона на основе экспериментально-статистического моделирования. На примере, приведенной блок-схемы расчета составов бетона, подробно описана последовательность расчетов. Суть расчетов заключается в том, что трехфакторная математическая модель параметра свойства ячеистого бетона, который необходимо гарантировать, сводится к уравнению второго порядка. После этого определяются корни уравнения. Их подставляют в математическую модель и определяют состав бетона в натуральных значениях переменных факторов. После этого определяется стоимость состава, которая заносится в массив. Далее изменяется один из факторов, соответственно, установленного шага, и цикл повторяется. На последней стадии обрабатывается сформированный массив и определяется состав с минимальной стоимостью материалов. Апробация разработанного программного обеспечения осуществлена обработкой и вычислениями трех факторного эксперимента. В результате определен состав ячеистого бетона, который обеспечивает нужную прочность пенобетона с минимальной стоимостью материалов.
\end{abstract}

Ключевые слова: пенобетон, алгоритм, блок-схема, компьютерная программа, расчет состава бетона, себестоимость.

Стаття надійшла до редакції 10.03.2021 